\title{
Effect of Surface Sealant on the Color Stability of Composite Resin Restorations
}

\author{
Fernanda VALENTINI \\ Simone Gomes Dias de OLIVEIRA \\ Guilherme Zdradk GUIMARÃES \\ Renata Pereira de Sousa BARBOSA \\ Rafael Ratto de MORAES
}

Dental School, UFPel - Federal University of Pelotas, Pelotas, RS, Brazil

\begin{abstract}
This study investigated the effect of sealant application on the color stability of composite resin restorations. Cavities in bovine incisors were restored with composite resin (Opallis; FGM) and the teeth were assigned to 4 groups ( $\mathrm{n}=10)$. A sealant (Fill Glaze; Vigodent) was applied over the restorations of 2 groups. Baseline color measurements based on the CIEL*a*b* system were carried out using a spectrophotometer. Half the number of specimens was immersed in distilled water, and half was immersed in coffee $4 \mathrm{~h} /$ day. Color measurements were repeated after 1 h, 24 h, 7 days and 3 months. Data for each immersion solution were separately subjected to a twoway repeated measures ANOVA and Tukey's test $(\alpha=0.05)$. For the group without sealant immersed in water, no significant differences were observed among the periods ( $\mathrm{p} \geq 0.138)$, but the color was different compared with baseline $(\mathrm{p}<0.001)$. For the group with sealant application, the periods baseline, $1 \mathrm{~h}$ and 3 months presented similar results ( $\mathrm{p} \geq 0.924)$. For groups immersed in coffee, when the sealant was not used, no significant differences were detected between the baseline and the periods $1 \mathrm{~h}$ and $24 \mathrm{~h}(\mathrm{p} \geq 0.499)$, but the color changed significantly thereafter $(\mathrm{p} \leq 0.003)$. In the group with sealant, significant differences were detected for all periods compared with each other $(\mathrm{p}<0.001)$. In conclusion, application of sealant dramatically increased the staining of the restorations exposed to coffee.
\end{abstract}

Key Words: coffee, color, composite resins, immersion, spectrophotometry.

\section{INTRODUCTION}

Composite resin restorations may present color alteration as a function of aging (1). The literature indicates that this effect may be related to factors such as the material's formulation, finishing and polishing procedures, and staining agent they are exposed (2-8). The relative porosity of the restorative and absorption/ adsorption of oral fluids may allow staining agents to penetrate the material; surface degradation may be accelerated, favoring extrinsic pigmentation (2).

Resin surface sealants are routinely employed in dentistry to seal pit and fissures on the occlusal faces of posterior teeth, creating a smooth, easy to clean surface. Sealants have also been applied over composite restorations to fill the surface irregularities in an endeavor to improve the surface luster, marginal sealing and wear resistance (9-13). The use of surface sealants could also affect the absorption of pigments and color stability of composite restorations; however, contrasting findings are reported in the literature $(14,15)$.

The aim of this study was to investigate the effect of sealant application on the 3-month color stability of composite resin restorations immersed in water or black coffee solution. The hypotheses tested were that (i) the use of sealant increases the color stability of the restorations, irrespective of the immersion medium, and (ii) longer immersion periods leads to higher color alteration for either immersion medium.

\section{MATERIAL AND METHODS}

Forty bovine incisors were used. Standard Class $\mathrm{V}$ cavities $(5 \times 5 \mathrm{~mm}$, depth $2 \mathrm{~mm})$ were prepared in the buccal faces, with incisal margins placed in enamel and cervical margins in dentin. Preparations were carried out using \#330 carbide burs (KG Sorensen, Barueri, SP, Brazil) under high speeds, with air/water cooling. 
The etch-and-rinse adhesive system Single Bond 2 (3M ESPE, St. Paul, MN, USA) was applied to the cavities according to the manufacturer's instructions. The bonding agent was photoactivated for $20 \mathrm{~s}$ using a light-emitting diode unit (Radii; SDI, Bayswater, Victoria, Australia) with $1400-\mathrm{mW} / \mathrm{cm}^{2}$ irradiance. The cavities were incrementally restored with a microhybrid composite resin (Opallis; FGM, Joinville, SC, Brazil; shade A2). Each increment was photoactivated for 40 $\mathrm{s}$, and a transparent polyester strip was placed over the restoration before the last increment was cured.

Finishing was carried out with a scalpel blade and polishing was performed using fine, superfine and ultrafine aluminum oxide discs (Sof-Lex system; 3M ESPE) and diamond polishing compound (Diamond; FGM). The teeth were randomly assigned to 4 groups $(\mathrm{n}=10)$; a resin surface sealant (Fill Glaze; Vigodent, Rio de Janeiro, RJ, Brazil) was applied over the restorations of 2 groups. The surfaces were abundantly rinsed with air/water spray, dried with compressed air and a thin layer of the sealant applied. Excess sealant was removed with air stream and the material photoactivated for $20 \mathrm{~s}$. A layer of hydrosoluble gel was applied over the cured sealant and photoactivation carried out again for $20 \mathrm{~s}$. After rinsing the specimens with water and air-drying, a double layer of nail varnish was applied to all surfaces of each tooth except for the restoration and a margin of $0.5 \mathrm{~mm}$ around it.

Baseline color measurements were performed using a spectrophotometer (Easyshade; Vita Zähnfabrik, Bad Säckingen, Germany). The contact guide was positioned on the center of the restoration, and 3 consecutive readings were made and averaged. Color measurements were based on the CIEL*a*b* system, as previously described (3). Half the number of specimens was immersed in distilled water and the other half in non-sweetened black coffee solution (Café Pacheco, Porto Alegre, RS, Brazil); the solution was prepared using a 3:10 powder:water mass ratio. The specimens were individually soaked in $30 \mathrm{~mL}$ of solution and kept at $37^{\circ} \mathrm{C}$ throughout the experiment. The specimens immersed in coffee were soaked $4 \mathrm{~h} /$ day in the solution, then in distilled water for the remaining period.

The color measurements were repeated after $1 \mathrm{~h}$, 24 h, 7 days and 3 months of exposure; the specimens were removed from the immersion medium, rinsed with distilled water and dried with absorbent paper. The color differences $\left(\Delta \mathrm{E}^{*}\right)$ were calculated as previously described (3). Data for each immersion solution were separately subjected to a two-way repeated measures ANOVA (surface treatment $\mathrm{x}$ immersion period) and Tukey's test $(\mathrm{p}<0.05)$.

\section{RESULTS}

Results for specimens immersed in water and coffee are shown in Tables 1 and 2, respectively. For specimens immersed in water, the factor 'immersion

Table 1. Means (standard deviations) for color and color alteration $\left(\Delta \mathrm{E}^{*}\right)$ for groups immersed in distilled water $(\mathrm{n}=10)$.

\begin{tabular}{lccccc}
\hline \multirow{2}{*}{$\begin{array}{l}\text { Immersion } \\
\text { period }\end{array}$} & \multicolumn{2}{c}{ Without sealant } & & \multicolumn{2}{c}{ With sealant } \\
\cline { 2 - 3 } \cline { 5 - 6 } \cline { 5 - 6 } Baseline & $\Delta \mathrm{E}^{*}$ & Color & & Color & $\Delta \mathrm{E}^{*}$ \\
\hline $\mathrm{h}$ & -- & $5.3(1.4) \mathrm{A}, \mathrm{a}$ & & $2.1(0.9) \mathrm{B}, \mathrm{b}$ & -- \\
$24 \mathrm{~h}$ & $-2.6(1.5)$ & $2.7(0.9) \mathrm{A}, \mathrm{b}$ & & $1.8(0.8) \mathrm{A}, \mathrm{b}$ & $-0.3(0.8)$ \\
7 days & $-1.9(1.9)$ & $3.4(0.8) \mathrm{A}, \mathrm{b}$ & & $3.8(0.9) \mathrm{A}, \mathrm{a}$ & $1.7(0.9)$ \\
3 months & $-2.1(1.6)$ & $3.2(0.9) \mathrm{A}, \mathrm{b}$ & & $3.2(1.1) \mathrm{A}, \mathrm{a}$ & $1.1(1.2)$ \\
\hline
\end{tabular}

Different uppercase letters in a same row indicate significant differences for using or not sealant. Different lowercase letters in a same column indicate significant differences for immersion period $(\mathrm{p}<0.05)$.

Table 2. Means (standard deviations) for color and color alteration $\left(\Delta \mathrm{E}^{*}\right)$ for groups immersed in coffee $(n=10)$.

\begin{tabular}{lccccc}
\hline \multirow{2}{*}{$\begin{array}{l}\text { Immersion } \\
\text { period }\end{array}$} & \multicolumn{2}{c}{ Without sealant } & & \multicolumn{2}{c}{ With sealant } \\
\cline { 2 - 3 } \cline { 5 - 6 } \cline { 5 - 6 } Baseline & $\Delta \mathrm{E}^{*}$ & Color & & Color & $\Delta \mathrm{E}^{*}$ \\
\hline $\mathrm{h}$ & -- & $5.0(0.9) \mathrm{A}, \mathrm{c}$ & & $1.8(0.8) \mathrm{B}, \mathrm{e}$ & -- \\
$24 \mathrm{~h}$ & $0.7(1.5)$ & $5.7(1.3) \mathrm{A}, \mathrm{c}$ & & $6.7(1.4) \mathrm{A}, \mathrm{d}$ & $4.9(1.8)$ \\
7 days & $0.3(0.9)$ & $5.3(1.0) \mathrm{B}, \mathrm{c}$ & & $12.6(1.7) \mathrm{A}, \mathrm{c}$ & $10.7(1.8)$ \\
3 months & $9.1(2.0)$ & $14.1(1.5) \mathrm{A}, \mathrm{a}$ & & $26.1(1.4) \mathrm{A}, \mathrm{a}$ & $21.7(8.1)$ \\
\hline
\end{tabular}

Different uppercase letters in a same row indicate significant differences for using or not sealant. Different lowercase letters in a same column indicate significant differences for immersion period $(\mathrm{p}<0.05)$. 
period' was significant $(\mathrm{p}<0.001)$, whereas the factor 'surface treatment' was not significant $(\mathrm{p}=0.063)$; the interaction between the 2 factors was significant $(p<0.001)$. For specimens immersed in coffee, both the factors 'immersion period' and 'surface treatment' were significant, and so was their interaction $(\mathrm{p}<0.001)$.

For the group without sealant immersed in water, no significant differences $(\mathrm{p} \geq 0.138)$ were observed among the immersion periods, although a significant reduction $(p<0.001)$ in the $E$ values was detected for all periods compared with the baseline. For the group with sealant application, the periods baseline, $1 \mathrm{~h}$ and 3 months presented similar results ( $\mathrm{p} \geq 0.924)$, showing significantly lower $E$ values $(p \leq 0.044)$ compared with the periods $24 \mathrm{~h}$ and 7 days, which were similar to each other $(\mathrm{p}=0.481)$.

For groups immersed in coffee, when the sealant was not used, no significant differences ( $p \geq 0.499)$ were detected between the baseline and the periods $1 \mathrm{~h}$ and $24 \mathrm{~h}$. After 7 days, the E value was significantly higher $(p \leq 0.003)$ compared with the earlier periods; after 3 months, the E value was significantly higher $(\mathrm{p}<0.001)$ than all the other periods. In the group with application of sealant, significant differences $(\mathrm{p}<0.001)$ were detected for all immersion periods compared with each other.

\section{DISCUSSION}

The results of the present study suggest increased color stability provided by the sealant when the specimens were immersed in water, probably related to the smoother surface provided by the sealant. This effect, however, was observed only during the first week of immersion, and therefore might not be of clinical significance. Comparing the groups with and without sealant immersed in water, a significant difference was detected for the baseline color: the group with sealant showed lower $\mathrm{E}$ value. This indicates that the use of a sealant may change the color of the restoration, which might be a possible side effect of sealant application.

The present results also indicate that the coffee solution has a stronger staining ability than water, which has been credited as an effect of absorption and penetration of yellow colorants of coffee into the organic phase of the materials (8). The staining yielded by exposure to coffee was time-dependent. Although a relative time-dependent staining was also observed for the group without sealant, the use of sealant dramatically increased the staining of the restorations immersed in coffee. This is probably related to the fact that, unlike the restorative composite, no filler particles are present in the resin sealant. The glass filler particles are generally inert and should not absorb fluids, the amount of water/ colorant uptake being dependent on the resin content of the material. In addition, the presence of more hydrophilic comonomers in the resin sealant compared with the composite resin might also explain the decreased color stability.

Based on previous studies $(16,17)$, a $\Delta \mathrm{E}^{*} \geq 3.3$ is considered visually perceptible and clinically unacceptable. For specimens immersed in water, $\Delta \mathrm{E}^{*}$ values $>3.3$ were not detected. For specimens immersed in coffee, $\Delta \mathrm{E}^{*}$ values $>3$ were observed for all groups with sealant, and also for the group without sealant after immersion in coffee for 3 months. These findings reinforce the greater staining potential of coffee compared with water, and also that application of a resin surface sealant may have a detrimental effect by decreasing the color stability of composite restorations. Doray et al. (14), however, reported that surface sealants could improve the resistance to staining of a composite resin provisional material. Differences in the effectiveness among resin sealants in providing staining resistance may be attributed to differences in formulation of the materials.

In conclusion, the first hypothesis tested could not be accepted, as the use of a resin surface sealant increased the staining of composite resin restorations exposed to coffee solution. The second hypothesis tested could not be accepted either because longer immersion periods generated higher color alteration only for specimens immersed in coffee. Clinical evaluations on the performance of composite resin restorations covered with a resin surface sealant are still lacking.

\section{RESUMO}

Este estudo avaliou o efeito da aplicação de selante na estabilidade de cor de restaurações de compósito. Cavidades foram restauradas em incisivos bovinos com resina composta (Opallis, FGM) e os dentes separados em quatro grupos $(n=10)$. O selante (Fill Glaze; Vigodent) foi aplicado sobre as restaurações em dois grupos. Aferição inicial de cor baseada no sistema CIEL*a*b* foi realizada com espectrofotômetro. Metade do número de espécimes foi imersa em água destilada, e metade imersa $4 \mathrm{~h} /$ dia em café. Aferições de cor foram repetidas após 1 h, 24 h, 7 dias e 3 meses. Os dados para cada solução de imersão foram submetidos separadamente à Análise de Variância de 2 vias para medidas repetidas e teste de Tukey $(\alpha=0,05)$. Para o grupo sem selante imerso em água, não foram observadas diferenças entre os períodos $(\mathrm{p} \geq 0,138)$, mas a cor foi diferente comparada à 
inicial $(\mathrm{p}<0,001)$. Para o grupo com selante, os períodos inicial, 1 h e 3 meses apresentaram resultados similares $(p \geq 0,924)$. Para os grupos imersos em café, quando o selante não foi utilizado, não foram detectadas diferenças entre os períodos inicial, $1 \mathrm{~h}$ e $24 \mathrm{~h}(\mathrm{p} \geq 0,499)$, mas a cor alterou significativamente após ( $\mathrm{p} \leq 0,003)$. No grupo com selante, diferenças significativas foram detectadas para todos os períodos comparados entre $\operatorname{si}(\mathrm{p}<0,001)$. Em conclusão, a aplicação de selante aumentou drasticamente o manchamento das restaurações expostas ao café.

\section{REFERENCES}

1. Pires-de-Souza FC, Garcia LF, Hamida HM, Casemiro LA. Color stability of composites subjected to accelerated aging after curing using either a halogen or a light emitting diode source. Braz Dent J 2007;18:119-123.

2. Bagheri R, Burrow MF, Tyas M. Influence of food-simulating solutions and surface finish on susceptibility to staining of aesthetic restorative materials. J Dent 2005;33:389-398.

3. Fontes ST, Fernandez MR, de Moura CM, Meireles SS. Color stability of a nanofill composite: effect of different immersion media. J Appl Oral Sci 2009;17:388-391.

4. Jung M, Sehr K, Klimek J. Surface texture of four nanofilled and one hybrid composite after finishing. Oper Dent 2007;32:45-52.

5. Mundim FM, Garcia LF, Pires-de-Souza FC. Effect of staining solutions and repolishing on color stability of direct composites. J Appl Oral Sci 2010;18:249-254.

6. Rutkunas V, Sabaliauskas V, Mizutani H. Effects of different food colorants and polishing techniques on color stability of provisional prosthetic materials. Dent Mater J 2010;29:167-176.

7. Topcu FT, Sahinkesen G, Yamanel K, Erdemir U, Oktay EA, Ersahan S. Influence of different drinks on the colour stability of dental resin composites. Eur J Dent 2009;3:50-56.
8. Um CM, Ruyter IE. Staining of resin-based veneering materials with coffee and tea. Quintessence Int 1991;22:377-386.

9. Cilli R, de Mattos MC, Honorio HM, Rios D, de Araujo PA, Prakki A. The role of surface sealants in the roughness of composites after a simulated toothbrushing test. J Dent 2009;37:970-977.

10. May KN Jr., Swift EJ Jr., Wilder AD Jr., Futrell SC. Effect of a surface sealant on microleakage of Class V restorations. Am J Dent 1996;9:133-136.

11. Pardi V, Sinhoreti MA, Pereira AC, Ambrosano GM, Meneghim MC. In vitro evaluation of microleakage of different materials used as pit-and-fissure sealants. Braz Dent J 2006;17:49-52.

12. Silva Santana SV, Bombana AC, Florio FM, Basting RT. Effect of surface sealants on marginal microleakage in Class $\mathrm{V}$ resin composite restorations. J Esthet Restor Dent 2009;21:397-404.

13. Fernández EM, Martin JA, Angel PA, Mjör IA, Gordan VV, Moncada GA. Survival rate of sealed, refurbished and repaired defective restorations: 4-year follow-up. Braz Dent J 2011;22:134139.

14. Doray PG, Eldiwany MS, Powers JM. Effect of resin surface sealers on improvement of stain resistance for a composite provisional material. J Esthet Restor Dent 2003;15:244-249.

15. Garcia PP, Neto ER, Santos PA, Campos JA, Dibb RG. Influence of surface sealant on the translucency of composite resin: effect of immersion time and immersion media. Mat Res 2008;11:193-197.

16. Ruyter IE, Nilner K, Moller B. Color stability of dental composite resin materials for crown and bridge veneers. Dent Mater 1987;3:246-251.

17. Vichi A, Ferrari M, Davidson CL. Color and opacity variations in three different resin-based composite products after water aging. Dent Mater 2004;20:530-534.

Received March 13, 2011 Accepted July 8, 2011 